\title{
VALIDATION OF NON-FORMAL AND INFORMAL LEARNING FROM A EUROPEAN PERSPECTIVE - LINKING VALIDATION ARRANGEMENTS WITH NATIONAL QUALIFICATIONS FRAMEWORKS
}

\begin{abstract}
The paper analyses European policy on the validation of non-formal and informal learning, which is presented as a "salvation narrative" that can improve the functioning of the labour market, provide a way out from unemployment and strengthen the competitiveness of the economy. Taking as our starting point recent findings in adult education theory on the validation of non-formal and informal learning, we aim to prove the thesis that what European validation policy promotes is above all economic purpose and that it establishes a "Credential/Credit-exchange" model of validation of non-formal and informal learning. We proceed to ecxamine the effect of European VNIL policy in selected European countries where validation arrangements are linked to the qualifications framework. We find that the "Credential/ Credit-exchange" validation model was first established in a few individual European countries and then transferred, as a "successful" model, to the level of common European VNIL policy.
\end{abstract}

Keywords: European policy, validation of non-formal and informal learning, national qualifications framework, adult education

\section{POTRJEVANJE NEFORMALNEGA IZOBRAŽEVANJA IN PRILOŽNOSTNEGA UČENIA Z EVROPSKE PERSPEKTIVE - POVEZOVANIE POSTOPKOV POTRJEVANIA Z NACIONALNIM OGRODJEM KVALIFIKACIJ - POVZETEK}

$V$ prispevku analiziramo evropsko politiko potrjevanja neformalnega izobraževanja in priložnostnega učenja, ki je predstavljena kot »pripoved odrešitve z z izboljšanje delovanja trga dela, izhod iz brezposelnosti in krepitev konkurenčnosti gospodarstva. Izhajajoč iz sodobnejših spoznanj v teoriji izobraževanja odraslih o vrednotenju neformalnega izobraževanja in priložnostnega učenja, dokazujemo tezo, da evropska politika vrednotenja spodbuja predvsem ekonomski namen, kakor tudi vzpostavlja »kvalifikacijsko/kreditni« model potrjevanja neformalnega izobraževanja in priložnostnega učenja. V nadaljevanju preučujemo vpliv evropske politike potrjevanja neformalnega izobraževanja in priložnostnega

Borut Mikulec, M. A., Center RS za poklicno izobraževanje, borutmikulec@yahoo.com 
učenja $v$ izbranih evropskih državah na primeru povezovanja postopkov potrjevanja z ogrodjem kvalifikacij ter ugotavljamo, da se je »kvalifikacijsko/kreditni« model potrjevanja uveljavil najprej v določenih evropskih državah in se kot »uspešen « model prenesel na raven skupne evropske politike potrjevanja neformalnega izobraževanja in priložnostnega učenja.

Ključne besede: evropska politika, potrjevanje neformalnega izobraževanja in priložnostnega učenja, nacionalno ogrodje kvalifikacij, izobraževanje odraslih

\section{INTRODUCTION: EUROPEAN POLICY ON VALIDATION OF NON- FORMAL AND INFORMAL LEARNING}

During the ten-year period (2000-2010) characterised by the Lisbon Strategy (European Council, 2000), all the fundamental documents that contribute to the formation of European adult education policy in this period (e.g. Commission of the European Communities, 2006; European Parliament, 2008) highlight the need to establish effective systems for the validation of non-formal and informal learning (VNIL) in EU Member States. In the context of lifelong learning, A Memorandum on Lifelong Learning (Commission of the European Communities, 2000) notes that the lifelong learning places greater focus on non-formal and informal learning than on formal education, and that non-formal learning is undervalued. With the aim of maintaining the competitiveness of the economy, the Memorandum therefore proposes that Member States develop a high-quality VNIL system. In this period the Council of the European Union (2004) adopted the Common European Principles for identification and VNIL, with the aim of ensuring greater comparability and transparency between VNIL approaches and methods in different countries. Although these principles are defined in very general terms, they do identify some key issues important for the development of the VNIL system in European countries (2009).

Starting from these principles, CEDEFOP (European guidelines for validating..., 2009) drew up the "European guidelines for validating non-formal and informal learning", which represent the practical tool for VNIL. These guidelines state that instruments such as the European qualifications framework for lifelong learning (EQF), Europass and ECVET/ ECTS can contribute to VNIL; that VNIL should be an integral part of national qualifications frameworks (NQF); that both formative and summative approaches to assessment are important in VNIL, the former for the identification of learning outcomes and the latter for their validation; that adult education represents the fundamental sub-system for the promotion of non-formal and informal learning; that the VNIL system should not lead to qualifications that have a "second-class" status in society; that the individual is at the centre of VNIL; that assessment methods are the same as in the formal education system, but both should be adapted to the non-standardised character of non-formal and informal learning (European guidelines for validating..., 2009, pp. 70-72).

In the next ten-year period (2010-2020), which is defined by Europe 2020: A strategy for smart, sustainable and inclusive growth (Europe 2020, 2010), the need to promote adult education and establish effective VNIL systems is expressed even more clearly. The 
fundamental document that defines European adult education policy in this period "encourage[s] the development of effective lifelong guidance systems, as well as integrated systems for the validation of non-formal and informal learning" (Council..., 2011, p. 3). To this end, in late 2012 the Council (2012) adopted the Recommendation on the validation of non-formal and informal learning, which recommends that Member States should have adequate VNIL arrangements in place by 2018 at the latest, in order to offer individuals the opportunity to demonstrate what they have learned outside formal education and to make use of that learning for their careers and further learning. Member States should put in place arrangements for VNIL which enable individuals a) to have knowledge, skills and competences acquired through non-formal and informal learning validated; and $b$ ) to obtain a full or a partial qualification on the basis of validated non-formal and informal learning experiences. Secondly, arrangements for VNIL should include four basic elements: i) identification, ii) documentation and iii) assessment of an individual's learning outcomes acquired through non-formal and informal learning, and iv) certification of the results of the assessment of an individual's learning outcomes acquired through non-formal and informal learning in the form of a qualification or credits leading to a qualification. Thirdly, in arrangements for VNIL, Member States should apply certain principles, for example that VNIL arrangements are linked to the NQF and in line with the EQF; that guidelines in relation to VNIL are available to individuals and guidance on the VNIL system is freely accessible; that individuals who are unemployed have the opportunity to undergo a "skills audit" aimed at identifying their knowledge, skills and competences; that (partial) qualifications obtained by means of VNIL are based on the same standards as qualifications obtained through formal education, etc. And fourthly, all relevant stakeholders should be included in arrangements relating to the VNIL system (Council ..., 2011, pp. 3-4). The basic logic of the Recommendation is in line with the discourse of Europe 2020. The instrumental role of VNIL is highlighted, since "the validation of learning outcomes" through non-formal and informal learning should greatly increase "employability and mobility" and provide "increasing motivation for lifelong learning, particularly in the case of the socio-economically disadvantaged or the low-qualified" (Council ..., 2011, p. 1). The discourse of crisis is emphasised, because at a time when the EU "is confronted with a serious economic crisis which has caused a surge in unemployment, especially among young people, and in the context of an ageing population", VNIL has an even more important contribution to make in improving the functioning of the market, "in promoting mobility and in enhancing competitiveness and economic growth" (Council ..., 2011, p. 1). VNIL is thus presented as a "salvation narrative" that can improve the functioning of the labour market, provide a way out of unemployment and strengthen European competitiveness and economic growth (cf. Andersson, 2008).

Ever since the Lisbon period, the emerging European policy on VNIL has identified the linking of the VNIL system to the national qualifications framework (NQF) as a key element in the establishment of effective VNIL systems in Europe. The element that links the VNIL system to the NQF is the concept of learning outcomes (Analysis and overview..., 2015, p. 43). The importance of the NQF for VNIL lies in the fact that where 
qualifications are defined by learning outcomes, we can use level descriptors to place them at the appropriate NQF level and also assess them independently of the route by which they were obtained (Ermenc, 2014, p. 202). The NQF and VNIL should thus be working towards a common goal; they enable individuals to progress in their learning careers on the basis of learning outcomes, which are independent of duration and of specific educational programmes (European guidelines for validating..., 2009, p. 31).

Since learning outcomes and NQFs have been identified as a new formula for the establishment of effective VNIL systems in European countries, it is worth studying the link between NQFs and VNIL in more detail. First we will show that a VNIL system conceived in this way promotes, above all, the economic aims of VNIL while at the same time establishing a "Credential/Credit exchange" model of VNIL which is incapable of including different contexts of non-formal and informal learning. We will then consider, in the case of selected European countries, whether or not the "Credential/Credit-exchange" model of VNIL that is promoted by European VNIL policy is being implemented in these countries. Within this context we will show that this model of VNIL was first implemented in a few individual Member States and then transferred, as a "successful model", to the level of a common European VNIL policy.

\section{BETWEEN EUROPEAN POLICY AND VALIDATION OF NON-FORMAL AND INFORMAL LEARNING IN ADULT EDUCATION THEORY}

VNIL has represented one of the bigger challenges in adult education theory and practice ever since the late 1960s (Andersson, Fejes and Ahn, 2004). The aims of VNIL are essentially threefold: a) to achieve greater social justice (the VNIL system serves to help disadvantaged social groups gain access to formal education); b) to achieve greater economic development and competitiveness (the VNIL system enables the use of existing competences in the labour market); and c) to achieve social changes (through the VNIL system we can make society's knowledge visible and create better conditions to change it) (Andersson and Osman, 2008). Harris (1999) distinguishes between four models of VNIL: the "Procrustean" model, which is characteristic of vocational education, is linked to qualifications and qualifications frameworks and based on standards of knowledge or learning outcomes; the "Learning and Development" model, which is characteristic above all of higher education and linked to the aim of encouraging the individual's progress and democratic education; the "Radical" model, characteristic of social movements, in which experience has the potential to become a battleground, i.e. for the overcoming of oppression, and a space for VNIL; and the "Trojan-horse" model, which emphasises either applied and practically applicable knowledge which serves the interests of (economic) globalisation, or a critical orientation which questions the relationship between education and the economy and advocates the entry of non-traditional groups into higher education. Cameron (2012) considers various VNIL models and concludes that the majority of authors see the VNIL model somewhere between two poles: (a) a results-focused "Credential/Credit-exchange" model, characteristic of vocational qualifications frameworks, 
which enables the obtaining of credits and is based on a discourse of effectiveness, validation, competences, transparency and mobility, and (b) a "Developmental/Empowerment" model, which is focused on the process, enables the development and empowerment of individuals and represents a mechanism for social transformation.

Within the European VNIL policy, which is most clearly expressed in the Council Recommendations (2012), the aims of achieving greater social justice and social change have given way to the basic economic aims of greater competitiveness, prosperity, mobility and employability (Andersson, Fejes and Sandberg, 2013; Cavaco, Lafont and Pariat, 2014; Kelava, 2014). At the same time it is clear that the VNIL model linked to NQFs and learning outcomes corresponds above all to the Procrustean model or the "Credential/ Credit-exchange" model of VNIL, which has been the subject of much criticism. Various authors have pointed out that it has not contributed to the greater inclusion of disadvantaged groups in further education or to their greater employability (Cameron and Miller, 2004; Hamer, 2013); that the logic of learning outcomes requires VNIL candidates to evaluate their knowledge in a discourse which is alien to them, which means that a large part of their knowledge remains unrecognised, in that it is not reflected in the prescribed learning outcomes (Peters, 2006; Pokorny, 2006); that learning outcomes are presented in a depersonalised form as universal, neutral, objective and measurable knowledge which is independent of context (Hamer, 2013; Guo and Andersson, 2006); that learning outcomes are misleading because every attempt to divide specialised knowledge into "units" trivialises and marginalises the knowledge acquired, reducing it to chunks of unconnected information, and also denies the importance of "powerful knowledge" (Young and Allais, 2011); that learning outcomes represent the practice of "disciplining the subject", since they commit learners to predetermined goals that define what counts as "knowledge" and the method of demonstrating this (Edwards and Usher, 1994).

In contrast to this VNIL model, which has been the subject of much criticism, various authors (e.g. Hamer, 2013; Peters, 2006; Pokorny, 2006; Sandberg and Andersson, 2011) have highlighted the need to formulate a "reflexive" VNIL model. This is a model which encourages various forms of knowledge and does not impede its epistemological diversity (cf. Luke, Green and Kelly, 2010, p. x), which focuses on the process of reciprocal understanding between candidates and assessors, and which represents the learning process (not the final result). In this model, candidates must learn to express their tacit or communicative knowledge and use the specific language of the (educational) institutions that are responsible for VNIL, while assessors (teachers) should be directed towards what candidates know. In this way a space is created for dialogue: a space of mutual trust and respect that enables the identification of knowledge. The result is the establishment of a common language of understanding between assessors and candidates which facilitates the transfer of knowledge from non-formal education, informal learning and working life to the institutional (educational) context.

Let us now consider the influence of the European VNIL policy on VNIL policy in individual countries. 


\section{COMPARATIVE ANALYSIS OF NATIONAL POLICIES ON THE VALIDATION OF NON-FORMAL AND INFORMAL LEARNING IN SELECTED EUROPEAN COUNTRIES}

The purpose of this comparative analysis is to establish whether or not the "Credential/ Credit-exchange" model promoted by European VNIL is being implemented in selected European countries.

\section{Methodological framework}

The basic sources of the analysis are the national reports on the European inventory on VNIL prepared by Member States in conjunction with the Commission in 2014. These reports represent an in-depth insight into VNIL practices in individual European countries and are a key European tool to encourage Member States to further monitor and develop their VNIL systems (European inventory on validation..., 2014a).

The countries included in the analysis were selected with regard to three criteria: model of education, stage of development of the NQF and degree of development of the VNIL system. 1) In terms of the model of education we can differentiate between the Germanic (Germany, Austria), Francophone (France, Belgium), Anglo-Saxon (United Kingdom, Ireland) Scandinavian or Nordic (Denmark, Norway, Finland, Sweden, Iceland) and Mediterranean models (Spain, Portugal, Italy, Greece) (Bjørnåvold, 2000; Greinert, 2004). 2) Regarding the stage of development of the NQF, we distinguish between the design and development stage (e.g. Italy, Spain, Slovakia); the stage of formal adoption (e.g. Finland, Slovenia, Sweden); the early operational stage (e.g. Estonia, Germany, Portugal); and the advanced operational stage (e.g. England, Denmark, France, Ireland) (Analysis and overview ..., 2015). 3) Regarding the degree of development of the VNIL system, we distinguish between countries with a high (e.g. France, Norway, Portugal), medium-high (e.g. Denmark, Germany, United Kingdom), medium-low (e.g. Austria, Belgium, Czech Republic, Italy, Slovenia) or low degree of development of the validation system (e.g. Bulgaria, Greece, Hungary, Malta) (Hawley, Souto Otero and Duchemin, 2010).

We endeavoured to include one country from each educational model, so as to encompass the diversity of traditions in the European education area, and likewise to include countries where the NQF and VNIL system are at an advanced stage/high degree of development, since relevant data can only be obtained from countries which already have a NQF and VNIL system in place. Using these criteria, the following countries were chosen: England, Denmark, France, Germany and Portugal. The units of comparison were a) VNIL context and $b$ ) connection of the NQF with VNIL.

\section{Comparative analysis}

VNIL context

In England there is no single framework for VNIL at the national level. VNIL takes place by four main routes: 1) recognition of prior learning, which is linked to formal 
qualifications offered through the Qualifications and Credit Framework (QCF); 2) recognition of non-formal certificated learning via the QCF; 3) recognition of prior learning in higher education; and 4) recording progress and achievement in non-accredited learning (RARPA) in adult and community learning. Responsibility for implementation of the VNIL system is in the hands of individual providers, with agencies at the national level (e.g. OFQUAL, NIACE) providing guidelines for the various education and training sub-systems (European inventory on validation..., 2014b, pp. 4-5).

VNIL has been on the political agenda in Denmark for about 20 years and is seen as a key element in the promotion of lifelong learning. The VNIL system, which is developed at the national level, enables individuals to: a) be granted access to formal education programmes; b) obtain exemptions for parts of an education programme and/or have an individually tailored education programme; c) acquire a "certificate of competence" leading to access/exemptions in adult education programmes; d) obtain "education certificates" for parts of or a whole education programme. Implementation of VNIL is left to educational institutions. VNIL also has an important role in the non-formal sector. Tools have been developed which enable adults to document skills acquired through free-time ("hobby") activities, liberal education and civil society activities (European inventory on validation..., 2014c, pp. 3-5).

In France the VNIL system builds upon long-standing practices in the field of identification and recognition of prior learning and professional experience. The validation system, which is based on a clear legal framework, has taken shape in the framework of continuous vocational training and labour market policies. A key milestone was the adoption of legislation in 2002 which created the procedure known as "Validation of Experience" (Validation des acquis de l'expérience - VAE). This system is based on the validation of knowledge and skills acquired through prior experience and learning in a variety of contexts. Via the VAE system one can obtain any qualification officially recognised by the State and the social partners and included in the national directory of qualifications (Répertoire National des Certifications Professionnelles - RNCP), except when it is linked to a regulated profession. While the general parameters of VNIL at the national level are set by law, implementation of validation procedures is left to the providers. Alongside VAE, other procedures linked to the assessment of non-formal and informal learning also exist in France: 1) A mechanism known as Validation des acquis professionnels allows the recognition of professional and personal experience to enable access to a higher education programme through exemption from the normal requirements; 2) The "skills audit" or bilan de compétences aims at the identification of skills and competences of an individual, but is not considered a validation procedure as it does not lead to the award of a qualification (European inventory on validation..., 2014d, pp. 3-4).

The VNIL system in Germany is not developed as a standardised system at the national level but instead represents a colourful mosaic of local, regional and national approaches. 1) In the field of vocational education, one of the more visible approaches to VNIL at the legislative level is the "External Students' Examination" (Externenprüfung). This enables 
candidates to obtain a qualification from an apprenticeship on the condition that they can provide evidence of relevant work experience. 2) In the field of higher education candidates can be awarded credits for competences acquired at work, while qualified workers (master craftsmen) have access to higher education on the basis of validation of their work experience. 3) The Vocational Qualifications Assessment Law (Berufsqualifikationsfeststellungsgesetz - BQFG) adopted in 2013 gives migrants the right to have their qualifications verified and validated in Germany. The ProfilPass system, in place since 2005, aims to identify, document and assess competences regardless of where they were acquired, but does not provide for their certification (European inventory on validation..., 2014e, pp. 3-5).

Portugal introduced the National System for the Recognition, Validation and Certification of Competences (Sistema Nacional de Reconhecimento, Validação e Certificação de Competências - RVCC) in 2001. The VNIL system combines two main processes: a) the academic process, which aims to improve the qualification level of adults who do not have basic or secondary education certificates; and b) the vocational process, for adults who do not posess formal qualifications in their occupational fields. The institutions responsible for implementation of the VNIL system are the Centres for Qualification and Vocational Training. In the higher education sector, legislation passed in 2013 maintains that higher education institutions must formally adopt rules on VNIL, which must then be published in the official journal; VNIL is limited to a maximum of one third of the credits leading to the award of a specific qualification (European inventory on validation..., 2014f, pp. 3-4).

\section{Connection of the NQF with VNIL}

In England two of the possible VNIL routes are directly linked to the NQF (QCF). Using the NQF, credit can be awarded for individual units or whole qualifications. The basic principle of the NQF is that VNIL may be used to assess any unit within the NQF and that the opportunity to be awarded credit through VNIL is a universal entitlement of every individual. Individuals can apply for exemption from credits on the basis of their learning at work or on the basis of non-formal certification of education (internal training with an employer, adult education, community education). VNIL does not allow credit to be awarded for the partial completion of a unit; assessment of prior knowledge is carried out in accordance with the learning outcomes and assessment criteria defined in an individual unit and is identical to assessment for a qualification within the NQF. VNIL through the NQF represents a voluntary and individually tailored approach to the validation of achievements that can be summed up by the motto "claiming credit" (European inventory on validation..., 2014b, pp. 5-6).

In Denmark the NQF is still not directly linked to VNIL. The NQF includes qualifications from formal education, but the majority of these qualifications can also be obtained through the VNIL system. The assessment of competence, which takes place in relation to education programmes, is the responsibility of educational institutions. VNIL leads to 
the award of whole or partial qualifications. With the further development of the NQF, the framework will also include qualifications obtained in the private and non-formal sectors (European inventory on validation..., 2014c, pp. 6-7).

In France VNIL is directly linked to obtaining formal qualifications because the VAE system enables the award of any qualification included in the NQF (RNCP), except where the qualification relates to a regulated profession. VNIL (VAE) and the NQF (RNCP) are mutually dependent and complementary; a VAE procedure can be organised for all qualifications registered in the RNCP. The RNCP describes the content of each qualification; standards or référentiels de certification define competences in relation to the activities necessary for the performance of a given occupation and criteria for the verification of competences (European inventory on validation..., 2014d, pp. 6-7).

In Germany the NQF is not yet directly linked to VNIL since it currently only contains qualifications acquired during formal education. Procedures for the inclusion of non-formally and informally acquired competences in the framework are currently under preparation; on the basis of the Council's recommendations, the Federal Ministry of Education and Research has appointed a working group for VNIL. In this sense it may be expected that the NQF will be a catalyst for VNIL (European inventory on validation..., 2014e, pp. 5-7).

In Portugal the VNIL (RVCC) system is integrated with the NQF. NQF qualifications from levels 1 to 4 can be granted through the VNIL system. At the end of the process, adults are awarded a partial or a full certification, although an NQF qualification is only granted in the case of a full certification. Through VNIL, adults can obtain certification of basic and upper secondary education, where competences are assessed using standards from the "Key Competences in Adult Education and Training Reference Frameworks", and also vocational qualifications at the basic and upper secondary levels, where the assessment standards are those from the "National Catalogue of Qualifications" (European inventory on validation..., 2014f, pp. 4-5).

\section{CONCLUDING REMARKS}

Comparative analysis of VNIL policies in selected European countries shows that VNIL systems are a part of the wider lifelong learning policy or qualifications systems/frameworks in individual countries, and that in most cases countries have not established holistic policies to comprehensively regulate VNIL (with the exception of France). The aim of VNIL differs among the selected countries, and also among the various sub-systems of education and training: a) some countries have established a VNIL system through which candidates can obtain partial or full qualifications (England, France, Portugal); b) other countries enable candidates access to education/study programmes and/or validation of individual components of education/study programmes through VNIL (England, Denmark, France, Germany, Portugal); c) others again also have a system in place for the identification and documentation of informally acquired knowledge (Denmark, France, Germany). 
In England, France and Portugal, the VNIL system is directly linked to the NQF, which means that all qualifications (units in England) included in the framework can be obtained both in the formal education system and via VNIL (in Portugal this applies to qualifications at levels 1 to 4, while in England this rule does not apply to higher education qualifications, which are part of another framework ${ }^{1}$ ). From the point of view of rights to continue education or employment there are no differences between qualifications obtained in the formal education system and those obtained via VNIL. In all three countries VNIL is a part of the qualifications framework and leads to a qualification (or individual units in England), where the VNIL system is linked to the NQF via "standards of knowledge" (learning outcomes); qualifications defined by learning outcomes can be verified independently of the route by which they are obtained. In England these are units in the NQF, which among other things define the learning outcomes that candidates must achieve, as well as the verification criteria. In France these are qualification standards, which provide a description (of the content) of an individual qualification and are included in the NQF (RNCP). In Portugal a framework of key competences in adult education is used for the validation of basic and upper secondary education, while national catalogues of qualifications are used for the validation of vocational qualifications. Both types of standards prescribe (general or vocational) competences that candidates must prove in the verification process.

Denmark and Germany have not yet linked VNIL to their NQFs. Both countries report that with the further development of their NQFs they will establish mechanisms for the inclusion of qualifications (or competences in Germany) obtained in the non-formal education and the private sector. The logic of the connectivity between the NQF and VNIL in Denmark and Germany will be different from the one established in England, France and Portugal. Qualifications which can be obtained outside the formal education system and are currently not included in the NQF will be included once suitable validation mechanisms have been established. The emphasis is therefore on the preparation of adequate mechanisms for the incorporation of qualifications from the private sector and non-formal education into the NQF, rather than on the opening up different routes to obtain the (same) qualifications included within the NQF.

The "Credential/Credit-exchange" model of VNIL, which is promoted by European VNIL policy, has been implemented in England, France and Portugal. Since these countries began implementing the VNIL model well before the formulation of European VNIL policy, which found its clearest expression in the Council Recommendations from 2012, it is possible to view the promotion of this VNIL model at the European level as an infiltration of the VNIL system of individual countries at the (common) European level. We consider that the formulation of European VNIL policy can be understood as part of a process of "Europeanisation of education" (Alexiadou, 2014; Dale, 2009; Klatt, 2014), which includes both processes of adaptation of national education policies to European policies

1 Framework for Higher Education Qualifications (FHEQ). 
and the infiltration of the policies of the Member States into the formulation of common European education policy. Implementation of the "Credential/Credit-exchange" model of VNIL, which is linked to the NQF and learning outcomes, can therefore on the one hand be understood as an example of the transfer of VNIL policies from individual countries (England, France, Portugal) to the European level, and on the other as a process of adaptation of national policies to the European VNIL policy; under the influence of European VNIL policy, Denmark and Germany are already examining the possibility of using their NQFs and learning outcomes to develop the VNIL system.

Adult education researchers point out that linking VNIL to the NQF places the economic aims of VNIL in the foreground at the expense of other aims, and that the "Credential/Credit-exchange" model has not met the set aims of VNIL. In contrast to this model, authors have advocated a reflexive model of VNIL that is not based merely on pre-prepared standards (learning outcomes), but instead promotes the evaluation of various forms of knowledge and its epistemological diversity and is based on a process of mutual understanding between candidates and assessors in the VNIL process. European VNIL policy should balance the implementation of the "Credential/Credit-exchange" model with a reflexive model of VNIL, since this would enable the more balanced development of all three fundamental aims of VNIL - social justice, social change and a competitive economy - and support those VNIL initiatives that already exist in individual sub-systems of education in individual European countries (most frequently in the adult education). The implementation of European VNIL policy through the "Credential/Credit-exchange" model is something that European countries should approach cautiously and critically.

\section{REFERENCES}

Alexiadou, N. (2014). Policy Learning and Europeanisation in Education: the governance of a field and the transfer of knowledge. In A. Nordin and D. Sundberg (Eds.), Transnational Policy Flows in European Education: the making and governing of knowledge in the education policy field (pp. 123-140). Oxford: Symposium Books.

Analysis and overview of NQF developments in European countries. Annual report 2014. (2015). Luxembourg: Publications Office of the European Union.

Andersson, P. (2008). National Policy and the Implementation of Recognition of Prior Learning in a Swedish Municipality. Journal of Education Policy, 23(5), 515-531.

Andersson, P. and Osman, A. (2008). Recognition of Prior Learning as a Practice for Differential Inclusion and Exclusion of Immigrants in Sweden. Adult Education Quarterly, 59(1), 42-60.

Andersson, P., Fejes, A. and Ahn, S. (2004). Recognition of prior vocational learning in Sweden. Studies in the Education of Adults, 36(1), 57-71.

Andersson, P., Fejes and Sandberg, F. (2013). Introduction: Introducing research on recognition of prior learning. International Journal of Lifelong Education, 32(4), 405-411.

Bjørnåvold, J. (2000). Making learning visible: Identification, assessment and recognition of non-formal learning in Europe. Luxembourg: Office for Official Publications of the European Communities.

Cameron, R. (2012). Recognising workplace learning: the emerging practices of e-RPL and e-PR. Journal of Workplace Learning, 24(2), 85-104. 
Cameron, R. and Miller, P. (2004). RPL: why has it failed to act as a mechanism for social change? Retrieved from http://epubs.scu.edu.au/cgi/viewcontent.cgi?article=1030\&context=gcm_pubs.

Cavaco, C., Lafont, P. and Pariat, M. (2014). Policies of adult education in Portugal and France: the European Agenda of validation of non-formal and informal learning. International Journal of Lifelong Education, 33(3), 343-361.

Commission of the European Communities. (2000). A Memorandum on Lifelong Learning. Retrieved from http://arhiv.acs.si/dokumenti/Memorandum_on_Lifelong_Learning.pdf.

Commission of the European Union. (2006). Communication from the Commission: Adult learning: It is never too late to learn. Retrieved from http://eur-lex.europa.eu/legal-content/EN/TXT/PDF/?uri=CELEX:52006DC0614\&from=EN.

Council of the European Union. (2004). Conclusions of the Council and of the representatives of the Governments of the Member States meeting within the Council on Common European Principles for the identification and validation of non-formal and informal learning. Retrieved from http:// pjp-eu.coe.int/documents/1017981/3084932/Council_9175_04.pdf/45c4628f-1eef-4588-8e7b-abc09d112426.

Council of the European Union. (2011). Council Resolution on a renewed European agenda for adult learning. Retrieved from http://eur-lex.europa.eu/LexUriServ/LexUriServ.do?uri=OJ:C:2011:372:0 001:0006:en:PDF.

Council of the European Union. (2012). Council Recommendation of 20 December 2012 on the validation of non-formal and informal learning. Retrieved from http://eur-lex.europa.eu/legal-content/EN/ TXT/PDF/?uri=CELEX:32012H1222\%2801\%29\&from=EN.

Dale, R. (2009). Contexts, Constraints and Resources in the Development of European Education Space and European Education Policy. In R. Dale and S. Robertson (Eds.), Globalisation and Europeanisation in Education (pp. 23-44). Wallingford: Symposium.

Edwards, R. and Usher, R. (1994). Disciplining the subject: The power of competence. Studies in Education of Adults, 26(1), 1-15.

Ermenc, K. S. (2014). Qualifications Frameworks and Learning Outcomes as Supporters of Validation of Non-Formal and Informal Learning. In I. Ž. Žagar and P. Kelava (Eds.), From Formal to Non-Formal: Education, Learning and Knowledge (pp. 191-214). Newcastle upon Tyne: Cambridge scholars publishing.

Europe 2020. A strategy for smart, sustainable and inclusive growth. (2010). Retrieved from http://ec.europa.eu/eu2020/pdf/COMPLET\%20EN\%20BARROSO\%20\%20\%20007\%20-\%20Europe\%20 2020\%20-\%20EN\%20version.pdf.

European Council. (2000). Lisbon European Council 23 and 24 march 2000 presidency conclusions. Retrieved from http://www.europarl.europa.eu/summits/lis1_en.htm.

European guidelines for validating non-formal and informal learning. (2009). Luxembourg: Office for Official Publications of the European Communities.

European inventory on validation of non-formal and informal learning 2014: Final synthesis report. (2014a). Retrieved from https://cumulus.cedefop.europa.eu/files/vetelib/2014/87244.pdf.

European inventory on validation of non-formal and informal learning 2014: country report UK (England and Northern Ireland). (2014b). Retrieved from https://cumulus.cedefop.europa.eu/files/vetelib/2014/87079_UK_EN_NI.pdf.

European inventory on validation of non-formal and informal learning 2014: country report Denmark. (2014c). Retrieved from https://cumulus.cedefop.europa.eu/files/vetelib/2014/87054_DK.pdf.

European inventory on validation of non-formal and informal learning 2014: country report France. (2014d). Retrieved from https://cumulus.cedefop.europa.eu/files/vetelib/2014/87058_FR.pdf. 
European inventory on validation of non-formal and informal learning 2014: country report Germany. (2014e). Retrieved from https://cumulus.cedefop.europa.eu/files/vetelib/2014/87053_DE.pdf.

European inventory on validation of non-formal and informal learning 2014: country report Portugal. (2014f). Retrieved from https://cumulus.cedefop.europa.eu/files/vetelib/2014/87073_PT.pdf.

European Parliament. (2008). European Parliament resolution of 16 January 2008 on adult learning: it is never too late to learn. Retrieved from http://www.europarl.europa.eu/sides/getDoc.do?pubRef=-//EP//TEXT+TA+P6-TA-2008-0013+0+DOC+XML+V0//EN.

Fairbrother, G. P. (2007). Quantitative and Qualitative Approaches to Comparative Education. In M. Bray, B. Adamson and M. Mason (Eds.), Comparative Education Research: Approaches and Methods (pp. 39-62). Dordrecht: Springer.

Greinert, W. D. (2004). European vocational training systems: the theoretical context of historical development. In W. D. Greinert and G. Hanf (Eds.), Towards a history of vocational education and training (VET) in Europe in a comparative perspective. Proceedings of the first international conference October 2002, Florence (pp. 17-27). Luxembourg: Office for Official Publications of the European Communities.

Guo, S. and Andersson, P. (2006). The politics of difference: non/recognition of the foreign credentials and prior work experience of immigrant professionals in Canada and Sweden. In P. Andersson and J. Harris (Eds.), Re-theorising the Recognition of Prior Learning (pp. 183-204). Leicester: National Institute of Adult Continuing Education.

Hamer, J. (2013). Love, rights and solidarity in the recognition of prior learning (RPL). International Journal of Lifelong Education, 32(4), 481-500.

Harris, J. (1999). Ways of seeing the recognition of prior learning (RPL): what contribution can such practices make to social inclusion? Studies in the Education of Adults, 31(2), 124-138.

Hawley, J., Souto Otero, M. and Duchemin, C. (2010). 2010 update of the European Inventory on Validation of Non-formal and Informal Learning - Final Report. Retrieved from https://cumulus.cedefop. europa.eu/files/vetelib/2011/77643.pdf.

Kelava, P. (2014). (Recognition of) Non-Formal Learning: Beyond Formal Education. In I. Ž. Žagar and P. Kelava (Eds.), From Formal to Non-Formal: Education, Learning and Knowledge (pp. 215-246). Newcastle upon Tyne: Cambridge scholars publishing.

Klatt, M. (2014). Understanding the European Union and its Political Power. In M. Milana and J. Holford (Eds.), Adult Education Policy and the European Union. Theoretical and Methodological Perspectives (pp. 53-72). Rotterdam, Boston and Taipei: Sense Publishers.

Luke, A., Green, J. and Kelly, G. J. (2010). What Counts as Evidence and Equity? Review of Research in Education, 34(1), vii-xvi.

Peters, H. (2006). Using critical discourse analysis to illuminate power and knowledge in RPL. In P. Andersson and J. Harris (Eds.), Re-theorising the Recognition of Prior Learning (pp. 163-182). Leicester: National Institute of Adult Continuing Education.

Pokorny, H. (2006). Recognising prior learning: what do we know? In P. Andersson and J. Harris (Eds.), Re-theorising the Recognition of Prior Learning (pp. 261-281). Leicester: National Institute of Adult Continuing Education.

Sandberg, F. and Andersson, P. (2011). RPL for accreditation in higher education: as a process of mutual understanding or merely lifeworld colonisation? Assessment \& Evaluation in Higher Education, 36(7), 767-780.

Young, M. and Allais, S. (2011). The shift to outcome based frameworks. Key problems from a critical perspective. Austrian Open Access Journal of Adult Education, 14, 2-10. 